\title{
ACRL Board of Directors' actions, July 2000
}

\author{
Highlights of the Board's Annual Conference meetings
}

D uring the 2000 ALA Conference in Chicago, the ACRL Board of Directors met on July 8 and 11 and took the following actions.

\section{ACRL structure}

Rescinded the action to establish the Academic or Research Librarian of the Year Award Nominations Committee.

Created the Scholarly Communications Task Force with charge and composition.

\section{Disbanded the Professional Enhancement Committee.}

Approved extending invitations to former l3oard members and others identified by the ACRL President and immediate PastPresident for participation in the ACRL Fellows Program.

\section{ACRL governance}

Adopted revised policies for implementing the Strategic Plan.

Upon recommendation from the Professional Development Committee approved a revised charge for the committee.

\section{Extended the life of the Information} Literacy Competency Standards Task Force with a revised charge to develop a plan for marketing the Standards to the higher education community and for seeking en- dorsement of the Standards among higher education discipline organizations.

By consent, voted to establish the Information Literacy Advisory Committee and its charge and composition.

\section{Finances}

Voted to establish a task force to review the Initiative Fund situation for Chapters and suggest other means for supporting the professional development efforts of Chapters.

Approved a $\$ 1,500$ allocation to each section to be used in 2000-01 for implementing activities that support the new Strategic Plan. Sections are encouraged to be innovative and experimental in the use of these funds.

Adopted FY 2000-01 budgets for ACRL revenues of $\$ 2,764,811$ and expenses of $\$ 2,728,344$ and CHOICE revenues of $\$ 2,440,061$ and expenses of $\$ 2,417,020$.

Approved the revised Financial Plan for 2001 with changes in the amount of funds being transferred from the ACRL Operating Fund Balance in 2002 and 2003 from $\$ 500,000$ to $\$ 300,000$ and from the CHOICE Operating Fund Balance to $\$ 100,000$ for 2002 and 2003 .

\section{Government relations}

Endorsed upon recommendation of the Government Relations Committee the following resolutions: 


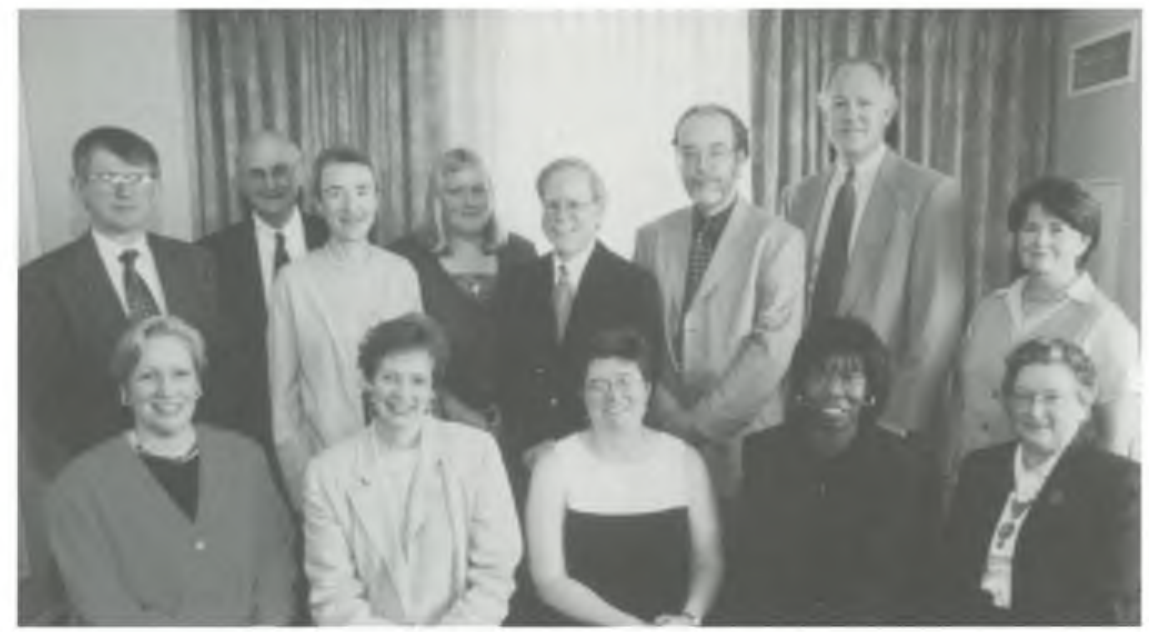

ACRL Board 1999-2000 (I to r): (back) Larry Hardesty, Paul E. Dumont, Mary Lee Sweat, Lois Cherepon, Robert F. Rose, William E. Brown, John Popko, Maureen Sullivan; (front) Helen H. Spalding. Betsy Wilson, Barbara Baxter Jenkins, Theresa S. Byrd, Dana C. Rooks. Not pictured: Althea $\mathrm{H}$. Jenkins.

- To encourage libraries and members to study issues of privacy and educate staff and patrons, and to support the ALA Office for Information Technology policy initiatives to enhance and reclaim privacy.

- That state ACRL Chapters be alerted to the existence of the Uniform Computer Information Transactions Act (UCITA); that state chapters notify the Washington Office if their state begins to take action on UCITA; and that state chapters educate their state house representative on this issue and work against the adoption of UCITA in their respective states

- That the ACRL Board, through the Council of Liaisons, urge the higher education community to promote consideration of the proposed legislation for distance education fair use exemption of the Digital Millennitum Copyright Act.

\section{Honors}

By consent, voted to submit the Resolution of Appreciation for Richard $M$. Dougherty to the ALA Council for endorsement.

\section{Intellectual freedom}

By consent, voted to accept the recommenclation from the ACRL Intellectual Free- dom Committee to take the Intellectual Freedom Principles for Academic Libraries to ALA Council for formal acioption as an interpretation of the Library Bill of Rights.

Endorsed the proposed changes to the Intellectual Freedom policies and the Intellectual Freedom manual as proposed by the ALA Intellectual Freedom Committee upon recommendation of the Intellectual Freedom Committee.

\section{Partnerships}

Voted to form a partnership with the TLT Group (Teaching, Learning, and Technology) to advance the New (V) TLTC-Virtual Teaching, Learning, and Technology Centers.

Voted to continue its support for ACRL's liaison activities with higher education organizations.

\section{Professional development}

Adopted the Statement on Professional Development upon recommendation of the Professional Development Committee.

Approved programs from 18 ACRL units for presentation during the ALA Annual Conference in San Francisco. 


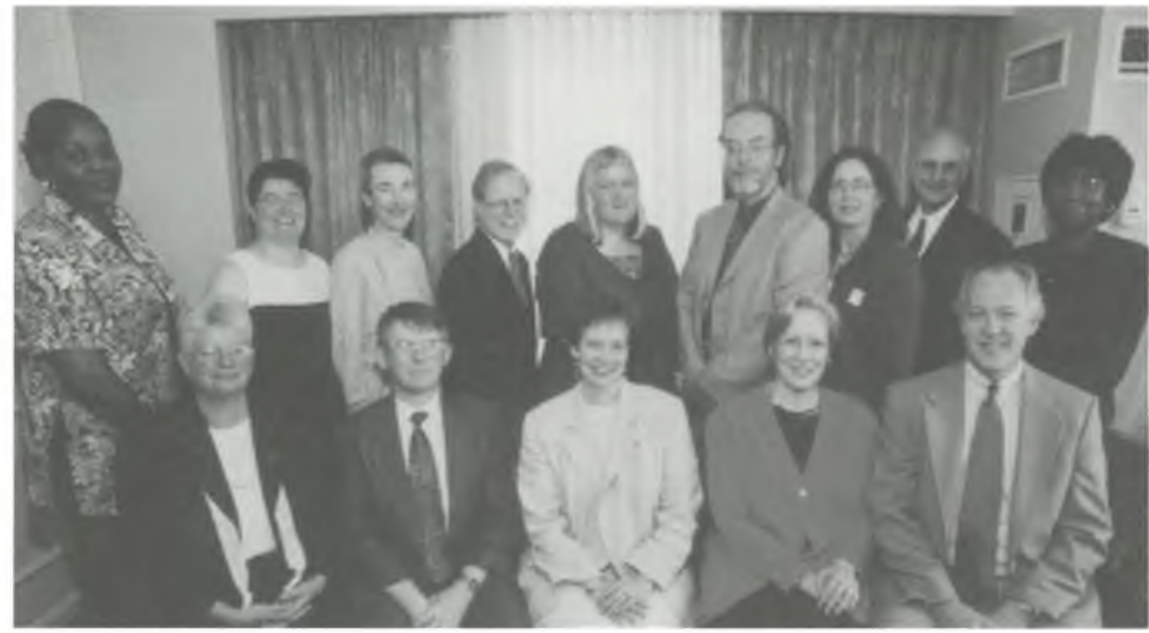

ACRL Board 2000-2001 (I to r): (back) Althea H. Jenkins, Barbara Baxter Jenkins, Mary Lee Sweat, Robert F. Rose, Lois Cheperon, William E. Brown, Deborah Dancik, Paul E. Dumont, Theresa S. Byrd; (front) Mary L. Reichel, Larry Hardesty, Betsy Wilson, Helen H. Spalding, John Popko.

Accepted the ALA Business Plan for the Web-based CE Programs and approved funding to support the development of course content.

Accepted the final report from the AASL/ ACRL Task Force on the Educational Role of
Libraries and requested that it be posted on the ACRL Web site.

\section{Scholarships}

Adopted the proposed policy for implementing ACRL's Scholarship Program.

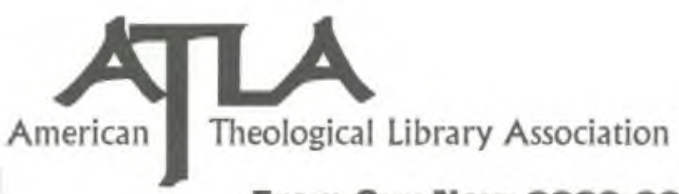

\section{From Our New 2000-2001 Catalog}

Products and Services of the American Theological Library Association:

- Preservation microfilm of more than 1,900 serial titles in religion

- The ATLA Religion Database, the premier index to journal articles, book reviews, and collection of essays in all fields in religion

- Eligibility to participate in the ATLA Mentoring Program and Library Materials Exchange Program

- ATLAS - The American Theological Library Association's new digital journal collection

Join more than 550 individuals who enjoy the many benefits of annual membership in ATLA.

The American Theological Library Association is a professional associarion of librarians who specialize in theology and religious stadies or who have an interest in she bibliography and litenature of religion.

\section{Why wait? Order your 2000-2001 ATLA Catalog today!}

Contact ATL $A$ at (888) 665-ATL $\mathcal{A}$ or c-mail us at atla@atla.com

Toll-free (North America): (888) 665-ATLA + http:// www.atla.com 